\title{
Effects of experimental drought on soil respiration and radiocarbon efflux from a temperate forest soil
}

\author{
WERNER BORKEN*†,KATHLEEN SAVAGE*, ERIC A. DAVIDSON* and \\ SUSAN E. TRUMBORE† \\ *Woods Hole Research Center, PO Box 296, Woods Hole, MA 02543, USA, †Department of Earth System Science, \\ University of California, Irvine, CA 92697, USA, †Department of Soil Ecology, University of Bayreuth, 95440 Bayreuth, Germany
}

\begin{abstract}
Soil moisture affects microbial decay of SOM and rhizosphere respiration (RR) in temperate forest soils, but isolating the response of soil respiration (SR) to summer drought and subsequent wetting is difficult because moisture changes are often confounded with temperature variation. We distinguished between temperature and moisture effects by simulation of prolonged soil droughts in a mixed deciduous forest at the Harvard Forest, Massachusetts. Roofs constructed over triplicate $5 \times 5 \mathrm{~m}^{2}$ plots excluded throughfall water during the summers of $2001(168 \mathrm{~mm})$ and $2002(344 \mathrm{~mm})$, while adjacent control plots received ambient throughfall and the same natural temperature regime. In 2003, throughfall was not excluded to assess the response of SR under natural weather conditions after two prolonged summer droughts. Throughfall exclusion significantly decreased mean SR rate by $53 \mathrm{mg} \mathrm{C} \mathrm{m}^{-2} \mathrm{~h}^{-1}$ over 84 days in 2001, and by $68 \mathrm{mg} \mathrm{C} \mathrm{m}^{-2} \mathrm{~h}^{-1}$ over 126 days in 2002, representing 10-30\% of annual SR in this forest and $35-75 \%$ of annual net ecosystem exchange (NEE) of C. The differences in SR were best explained by differences in gravimetric water content in the Oi horizon $\left(r^{2}=0.69\right)$ and the Oe/Oa horizon $\left(r^{2}=0.60\right)$. Volumetric water content of the A horizon was not significantly affected by throughfall exclusion. The radiocarbon signature of soil $\mathrm{CO}_{2}$ efflux and of $\mathrm{CO}_{2}$ respired during incubations of $\mathrm{O}$ horizon, $\mathrm{A}$ horizon and living roots allowed partitioning of SR into contributions from young $C$ substrate (including RR) and from decomposition of older SOM. RR (root respiration and microbial respiration of young substrates in the rhizosphere) made up $43-71 \%$ of the total $C$ respired in the control plots and $41-80 \%$ in the exclusion plots, and tended to increase with drought. An exception to this trend was an interesting increase in $\mathrm{CO}_{2}$ efflux of radiocarbon-rich substrates during a period of abundant growth of mushrooms.

Our results suggest that prolonged summer droughts decrease primarily heterotrophic respiration in the $\mathrm{O}$ horizon, which could cause increases in the storage of soil organic carbon in this forest. However, the $\mathrm{C}$ stored during two summers of simulated drought was only partly released as increased respiration during the following summer of natural throughfall. We do not know if this soil C sink during drought is transient or long lasting. In any case, differential decomposition of the $\mathrm{O}$ horizon caused by interannual variation of precipitation probably contributes significantly to observed interannual variation of NEE in temperate forests.
\end{abstract}

Keywords: heterotrophic respiration, $Q_{10}$, radiocarbon, rhizosphere respiration, soil drought, soil moisture, soil organic matter, soil respiration, soil wetting, temperate forest

Received 8 June 2004; revised version received 12 October 2004; accepted 20 September 2004

Correspondence: Werner Borken, Department of Soil Ecology, University of Bayreuth, Dr.-Hans-Frisch-Str. 1-3, 95440 Bayreuth, tel. + (049) 921 555741, fax + (049) 921 555799,

e-mail: werner.borken@uni-bayreuth.de
Introduction

Soil temperature and soil moisture influence the temporal dynamics of heterotrophic and autotrophic respiration in soil, which are major carbon fluxes from 
the terrestrial biosphere into the atmosphere. Moreover, these climatic variables influence the residence times and storage of soil organic carbon on a global scale, a pool that is two or three times larger than the carbon reservoir of the atmosphere (Sundquist, 1993; Eswaran et al., 1993). Exponential functions and derived $Q_{10}$ values, defined as the factor by which the rate of a chemical reaction increases when temperature increases by $10{ }^{\circ} \mathrm{C}$, are commonly used to describe the temperature dependency of soil respiration (SR) (total $\mathrm{CO}_{2}$ efflux from the forest floor surface) and to extrapolate the response of SR in terms of global warming. The temperature dependency of heterotrophic respiration is of particular importance for the sink or source strength of soils for atmospheric $\mathrm{CO}_{2}$.

In addition to the direct effects of temperature, however, possible changes in precipitation, evapotranspiration, and soil water content are likely to affect decomposition and SR. Increasing global surface temperatures are thought to change the amount, intensity and frequency of precipitation as well as evapotranspiration in most regions of the earth (IPCC, 2001). Over the 20th century, precipitation has increased by $7-12 \%$ in the mid- and high latitudes of the northern hemisphere, especially during autumn and winter, however, these increases varied both spatially and temporally. Future intensification of the hydrological cycle is expected to increase not only the frequency of severe droughts and wet spells but also to change the land area of dry and wet ecosystems (IPCC, 2001). Yet, it is not clear how fluxes and storage of carbon in terrestrial ecosystems will respond to extreme changes in precipitation.

The study by Goulden et al. (1996) suggested that temperate forests may become a larger net sink for atmospheric $\mathrm{CO}_{2}$ in years with extended summer droughts, because the decrease in SR was greater than the decrease in $\mathrm{CO}_{2}$ uptake by photosynthetic fixation during a dry summer. However, it is not clear whether this apparent $\mathrm{C}$ sink was transient or whether a drought-induced sink might persist. Interannual variation in net ecosystem exchange (NEE) of carbon observed at the Harvard Forest ranged from 1.2 to $2.5 \mathrm{Mg} \mathrm{ha}^{-1} \mathrm{yr}^{-1}$ during the period 1992-2000 (Barford et al., 2001), and part of that variation may be because of transient sources and sinks in the mineral soil and $\mathrm{O}$ horizon because of climatic effects on interannual variation of decomposition.

Soil moisture may limit or inhibit microbial decay of SOM at high and low water contents, whereas respiration of roots and microbes within the rhizosphere can be less affected by low water content, because many plants may compensate for soil water deficit in surface soils by water uptake from wetter, deeper soil depths. Many laboratory studies have shown that drying of soils can limit heterotrophic respiration when water potential falls below a certain threshold (Orchard \& Cook, 1983; Skopp et al., 1990; Howard \& Howard, 1993). This threshold may vary from soil to soil and within the soil profile as soil organisms are differently adapted to water stress. Fungi are generally better adapted to water stress than bacteria or soil fauna (Swift et al., 1979). Some soil organisms may survive during drought periods by formation of cysts, capsules and spores. This is particularly important in $\mathrm{O}$ horizons and top mineral soils where frequent drying and wetting may occur. We have recently shown that microorganisms in $\mathrm{O}$ horizon respond within a few seconds to wetting events as indicated by large $\mathrm{CO}_{2}$ peaks (Borken et al., 2003).

One of the difficulties in studying the effects of soil water content on SR is that precipitation, temperature, and evapotranspiration often covary, thus making it difficult to separate the effects of soil moisture and temperature on SR (Davidson et al., 1998). In the New England forest, for example, soils tend to dry as they warm during the summer and then become wet during the cold winter and spring. In this study, we sought to separate the effects of temperature and water content by conducting an experiment in which all plots experienced the same temperature regime, but throughfall was excluded in half of the plots. The effects of natural summer drought were observed in the control plots, and the effects of more severe, experimentally induced drought were observed in the throughfall exclusion plots. Excluding throughfall from small plots is logistically easier to accomplish in the middle of a forest than is adding large quantities of water through irrigation. Moreover, summer droughts are common in many temperate forests, and so simulation of an extended dry period is relevant to possible consequences of ongoing climatic disruption.

In addition to studying the effects of throughfall exclusion, we also sought to understand the mechanisms by which the effects occur. Radiocarbon measurements of $\mathrm{CO}_{2}$ from $\mathrm{SR}$ and soil air provide some information about the age and origin of respired carbon (Trumbore, 2000). Rhizosphere respiration (RR) yields $\mathrm{CO}_{2}$ that is usually derived from recent photosynthetic products, which should have ${ }^{14} \mathrm{C}$-signature of contemporary atmospheric $\mathrm{CO}_{2}$, whereas the decay of SOM can produce $\mathrm{CO}_{2}$ with a broad range of radiocarbon signatures, depending on the mean age of the carbon being decomposed. It is not clear whether drying and wetting of forest soils affect the decay of younger or older SOM under field conditions.

To evaluate the effect of intensive summer droughts on SR and radiocarbon efflux of a temperate forest soil, we established three roofed plots to exclude throughfall 
water in a mixed deciduous forest at the Harvard Forest in central Massachusetts. Soil droughts were simulated for 84 and 127 days during the summers of 2001 and 2002, respectively. We hypothesized (1) that severe summer droughts would decrease SR, mainly because of moisture limitations in the $\mathrm{O}$ horizon and (2) the average age of respired carbon would decrease during the droughts as a result of relatively stronger reductions in the decay of SOM compared with the reduction in RR. Furthermore, we hypothesized for the exclusion plots (3) that an increase in SR would occur in the posttreatment period of 2003, because relatively labile SOM may have been accumulated during the droughts in 2001 and 2002.

\section{Materials and methods}

\section{Site description}

The experiment was conducted in a mixed deciduous forest at the Prospect Hill tract of the Harvard Forest (42 $\left.32^{\prime} \mathrm{N}, 7211^{\prime} \mathrm{W}\right)$ at $340 \mathrm{~m}$ elevation, in Petersham, Massachusetts. The present forest developed after a hurricane in 1938 and is dominated by red maple (Acer rubrum L.) and red oak (Quercus rubra L.). Black birch (Betula lenta), white pine (Pinus strobus) and hemlock (Tsuga canadensis) are also present. There is little understory vegetation at these sites, and little light penetration to the forest floor. Before the hurricane, a similar mixed deciduous forest had developed on pastures abandoned since the late 19th century (Foster, 1992). The $\mathrm{O}$ horizon is $3-8 \mathrm{~cm}$ thick, stores about $7 \mathrm{~kg} \mathrm{~m}^{-2}$ of organic matter, and consists of $\mathrm{Oi}$, Oe and Oa horizons (Table 1). The ground vegetation, consisting mainly of ferns, covers about $30-100 \%$ of the soil surface during summer. As a result of 19th century agricultural use, the upper mineral soil is partly disturbed as indicated by varying depths of the A horizon from $2 \mathrm{~cm}$ down to $15 \mathrm{~cm}$, being $4.4 \mathrm{~cm}$ thick on average at our study site. The thickness of the total mineral soil varies from 40 to
$65 \mathrm{~cm}$ and has rock contents up to $40 \%$ of soil volume. The soil, a fine sandy loam on glacial till, is well aerated and has been classified as a well-drained Typic Dystrochrept.

The climate is dominated by warm and moist air from the Gulf of Mexico between May and December and by cold and dry subarctic air from December to March with April being a transitional month. Occasionally, cool and moist air from the north Atlantic can influence the weather. According to the long-term records at the Harvard Forest meteorological station, mean annual air temperature is $8.5^{\circ} \mathrm{C}$ and mean annual precipitation is $1050 \mathrm{~mm}$, with precipitation evenly distributed throughout the year. Average air temperatures were $9.7^{\circ} \mathrm{C}$ in $2001,8.4^{\circ} \mathrm{C}$ in 2002 , and $7.4^{\circ} \mathrm{C}$ in 2003 with means of $16.4,15.7$ and $15.6^{\circ} \mathrm{C}$ during the growing seasons from May 1 to October 31. The amounts of precipitation were $865 \mathrm{~mm}$ in 2001, $1110 \mathrm{~mm}$ in 2002 and $1311 \mathrm{~mm}$ in 2003 with 461, 583 and $717 \mathrm{~mm}$ during the growing seasons of 2001, 2002 and 2003, respectively. The soil is intermittently covered by thick layers of snow from late December to early April. The spring snowmelt often causes water saturation of soils in March and April. Potential evapotranspiration rates often exceed the precipitation from June to August, resulting in decreasing soil moisture (Greenland, 1996).

\section{Experimental design and installations}

The plots were located on a small plateau with slopes of $<3^{\circ}$. Three translucent roofs, each $5 \times 5 \mathrm{~m}^{2}$, were constructed $1.3 \mathrm{~m}$ above the forest floor in April 2001 in order to simulate severe soil droughts during the growing seasons of 2001 and 2002. The roofs were built of corrugated PVC panels with a rain gutter to exclude and remove all throughfall water from the exclusion plots, except perhaps small amounts that may have blown in horizontally around the perimeter. The exclusion plots were not trenched from the surrounding soil, because we did not wish to exclude roots from outside

Table 1 Some soil characteristics of the study site

\begin{tabular}{|c|c|c|c|c|c|}
\hline Horizon & $\begin{array}{l}\text { Depth } \\
(\mathrm{cm})\end{array}$ & $\begin{array}{l}\text { Amount of } \\
\text { soil }\left(\mathrm{kg} \mathrm{m}^{-2}\right)\end{array}$ & $\begin{array}{l}\text { Rock content } \\
\left(\mathrm{m}^{3} \mathrm{~m}^{-3}\right)\end{array}$ & $\begin{array}{l}\text { Bulk density } \\
(<2 \mathrm{~mm} \text { fraction }) \\
\left(\mathrm{g} \mathrm{cm}^{-3}\right)\end{array}$ & $\begin{array}{l}\text { Water-holding } \\
\text { capacity }(\mathrm{mm})\end{array}$ \\
\hline Oi & 2.0 & 0.53 & - & - & 1.9 \\
\hline Oe & 2.6 & 4.09 & - & - & 10.2 \\
\hline $\mathrm{Oa}$ & 2.1 & 2.60 & - & - & 4.7 \\
\hline $\mathrm{A}$ & 4.4 & 29.1 & 0.02 & 0.71 & 15 \\
\hline B I & 16.1 & 99.6 & 0.15 & 0.81 & 43 \\
\hline B II & 34.5 & 229.3 & 0.28 & 0.92 & 73 \\
\hline
\end{tabular}


the plots. This may have allowed lateral water transport and hydraulic lift by roots from outside into the exclusion plots. Throughfall water was excluded over 84 days from July 2 to September 24 in 2001 and over 127 days from May 7 to September 10 in 2002. Herbaceous plants were not visibly affected by throughfall exclusion and the roof construction. Roof panels were removed in September to enable undisturbed leaf litter fall and snow fall to the forest floor in the exclusion plots. Measurement in the posttreatment period without manipulation continued until November 10, 2003. A control plot of same size was established $2 \mathrm{~m}$ from each of the three exclusion plots.

In April 2001, three quantitative pits of $1 \times 1 \mathrm{~m}^{2}$ were established adjacent to the control and exclusion plots to determine some soil characteristics and soil physical parameters. The thickness and the gravel and rock contents were measured for each organic and mineral soil horizon down to the bedrock. We calculated the field capacity of each mineral soil horizon using gravimetric water contents of sieved soil samples $(<2 \mathrm{~mm})$, which were taken after snow melt. The A, B1 and B2 horizons may store 15,43 and $73 \mathrm{~mm}$, respectively, resulting in a water holding capacity of $131 \mathrm{~mm}$ for the total mineral soil (Table 1). A maximum water holding capacity of $16.8 \mathrm{~mm}$ has been determined for the total $\mathrm{O}$ horizon by wetting of undisturbed cores in the laboratory. According to the water retention curves from an adjacent study site (Savage \& Davidson, 2001), a water potential value of $-1.5 \mathrm{MPa}$, often used as an indicator of plant water stress, corresponds to a volumetric water content of about $8.5 \%$. Hence, we calculate that plant available water (PAW) is about $95 \mathrm{~mm}$ for the mineral soil and roughly $12 \mathrm{~mm}$ for the $\mathrm{O}$ horizon.

Soil pits were enlarged to about $2 \mathrm{~m}$ width for the installation of sensors within each control and exclusion plot. One wall of each pit was adjacent to a control plot and another wall of the same pit was adjacent to an exclusion plot. Six temperature and four TDR probes (CS615 Water Content Reflectometer, Campbell Scientific, Logan, UT, USA) were installed into each of these two pit walls to record soil temperatures and volumetric water contents. Additionally, six $1 / 8^{\prime \prime}$ stainlesssteel tubes of $1.8 \mathrm{~m}$ length were horizontally inserted about $50 \mathrm{~cm}$ into the pit walls at same depths as soil temperatures probes to measure $\mathrm{CO}_{2}$ gradients and their isotopic signature. The installation depths of probes and gas tubes varied from plot to plot because of differences in the thickness of soil horizons and in total depth of the soil profiles. The pits were refilled with soil and rocks after the installations.

Relative changes in gravimetric water content of the $\mathrm{Oi}$ and $\mathrm{Oe} / \mathrm{Oa}$ horizons were continuously measured during the growing season of 2001-2003 using DC half bridge sensors. At each plot, four and eight sensors were installed in the $\mathrm{Oi}$ and $\mathrm{Oe} / \mathrm{Oa}$ horizons, respectively. The DC half bridge sensors consisted of $1.59 \mathrm{~mm}$ thick and $9 \mathrm{~cm}^{2}$ large basswood piece (cut out from 1/ $16^{\prime \prime} \times 4^{\prime \prime} \times 24^{\prime \prime}$ basswood, Midwest Products CO. Inc., Hobart, IN, USA), connected to two stainless-steel alligator clips to $15-25 \mathrm{~m}$ lengths of 6 conductor 22 AWG cable (Belden, Richmond, Indiana, USA). All basswood pieces were replaced in April 2002 and 2003 because the wood was partly decomposed. Signals of DC half bridge sensors were converted into gravimetric water contents using calibration curves for the $\mathrm{Oi}$ horizon $(y=1.76 \times+0.01)$ and the Oe/Oa horizon $(y=2.63 \times-0.16)$ based on samples from our study site (Borken et al., 2003), where $\times$ is the voltage (V) of the DC half bridge sensors. Further information about this method is given by Borken et al. (2003).

Soil temperatures, volumetric water contents and signals from DC half bridge sensors were recorded at hourly intervals with two data loggers (CR10X, Campbell Scientific). Spatial variation in throughfall was measured weekly from April to November using 21 rain gauges evenly distributed in the study area. The amount of excluded throughfall water in the exclusion plots was calculated from these 21 rain gauges.

\section{$\mathrm{CO}_{2}$ measurements}

In each of the six plots, four PVC collars (Livestock Equipment Sales \& Service Inc., Riverside, Iowa, USA), $10 \mathrm{~cm}$ tall and $25 \mathrm{~cm}$ in diameter, were installed approximately $4 \mathrm{~cm}$ into the soil for the duration of the experiment. The collars were located at least $1 \mathrm{~m}$ from the perimeter of the plot, to avoid edge effects. SR was measured between 09:00 and 12:00 hours on a weekly basis during growing season and biweekly or monthly during dormant season. A vented chamber with a volume of $5.2 \mathrm{~L}$ was placed over a collar and connected to a portable infrared gas analyzer (IRGA, Licor 6252, Li-Cor Inc., Lincoln, Nebraska 68504, USA). Air was circulated in this closed system by a pump with a constant rate of $0.5 \mathrm{~L} \mathrm{~min}^{-1}$, and the increase in $\mathrm{CO}_{2}$ concentration was recorded every $12 \mathrm{~s}$ for a $5 \mathrm{~min}$ period. Linear regressions were performed to calculate the $\mathrm{CO}_{2}$ flux rates, which were corrected for changes in air pressure and air temperature within the headspace. A certified standard of $523 \mu \mathrm{LCO}_{2} \mathrm{~L}^{-1}( \pm 2 \%)$ was used to calibrate the IRGA each sampling day. More details about this method are given by Savage \& Davidson (2003). Soil temperature at $10 \mathrm{~cm}$ depth was manually measured next to each collar using a temperature probe.

After an anecdotal observation that $\mathrm{CO}_{2}$ fluxes seemed to increase whenever a fungal fruiting body appeared within a chamber collar, we installed four 
additional collars adjacent to our plots in July 2002, each including one fruiting body of the fungus family Russula spec. $\mathrm{CO}_{2}$ fluxes of these plots and the control and exclusion plots were measured at the same time.

In June 2002, one automated chamber was installed in each of the six plots to detect short-term changes in SR. The automated chambers, $35.5 \mathrm{~cm}$ in diameter and $15 \mathrm{~cm}$ tall, were connected to an IRGA (Licor 6252) and measured hourly SR fluxes. A detailed description of this automated system is given by Savage \& Davidson (2003).

Soil $\mathrm{CO}_{2}$ concentration profiles were determined by taking $10 \mathrm{~mL}$ samples with gas tight plastic syringes from each control and exclusion plot. The first $10 \mathrm{~mL}$ of gas were expelled to flush the stainless-steel tubes with ambient soil air. Then $10 \mathrm{~mL}$ gas samples were drawn and the syringes were closed with stopcocks. Gas samples were analyzed within $6 \mathrm{~h}$ in a laboratory at the Harvard Forest with the same IRGA as described above. The gas samples were injected into a 4-port valve, equipped with an open $2.5 \mathrm{~mL}$ sample loop which was immediately connected to a stream of $\mathrm{CO}_{2-}$ free air by switching the valve (Davidson \& Trumbore, 1995). Each injected gas sample was diluted in a mixing chamber of $120 \mathrm{~mL}$ volume before the gas mixture passed the IRGA and a datalogger recorded the $\mathrm{CO}_{2}$ concentrations in $1 \mathrm{~s}$ intervals. Four standards of 0.51 , $2.09,10.0$ and $25.0 \mathrm{mLCO}_{2} \mathrm{~L}^{-1}$ air certified to $\pm 5 \%$ were repeatedly measured to calibrate the system. Calibration curves were obtained by linear regressions of standard $\mathrm{CO}_{2}$ concentrations with their peak areas. The coefficient of variation for replicated injections of standard gases was usually $<2.5 \%$.

\section{Isotopic signature of $\mathrm{CO}_{2}$ from $\mathrm{SR}$, soil air, incubated roots and soil}

The radiocarbon content of $\mathrm{CO}_{2}$ from SR and soil air was determined on 12 occasions during the growing seasons in 2001-2003. We used the same type of chamber to sample isotopes in SR from two collars per control and exclusion plot which were used for regular SR measurements. After closure of each chamber, ambient $\mathrm{CO}_{2}$ trapped within the chamber headspace was removed from the chamber headspace using a pump, circulating air for $45 \mathrm{~min}$ at a rate of $0.5 \mathrm{~L} \mathrm{~min}^{-1}$ through a column filled with soda lime. In a second step, the $\mathrm{CO}_{2}$ concentration was then allowed to increase within the chambers for $15-25 \mathrm{~min}$ without air circulation in order to obtain $1-2 \mathrm{mg}$ of soil-derived $\mathrm{CO}_{2}-\mathrm{C}$ for isotopic analysis. Afterwards, the enriched chamber air was pumped for $15 \mathrm{~min}$ through a column filled with drierite and through a stainless-steel tube filled with 13X Molecular Sieve (Alltech Associates, Deerfield,
Illinois, USA) that quantitatively trapped $\mathrm{CO}_{2}$. At UC Irvine, $\mathrm{CO}_{2}$ was desorbed from the columns, cryogenically purified, and converted to graphite targets using sealed tube zinc reduction methods (Vogel, 1992). Radiocarbon analysis of these graphite targets were performed by accelerator mass spectrometry (AMS) (National Electrostatics Corporation, Middleton, Wisconsin, USA) at Lawrence Livermore National Laboratory, Livermore, California (LLNL) and at the W. M. Keck Carbon Cycle AMS facility at UC Irvine, California. More details on this field sampling method are given by Gaudinski et al. (2000). In 2002, nonspecified coarse and fine roots were collected from the top soil at three locations close to our plots to sample isotopes from RR. Immediately after sampling, the roots were rinsed with water to remove SOM. Visually dead roots were also removed. The clean, live roots were incubated in gastight jars for $2-3 \mathrm{~h}$, connected to the same sampling device that we used in the field to measure isotopes from SR. We assume that cutting and preparation of fine roots had no significant effect on isotopic signature of RR.

The isotopic signature of $\mathrm{CO}_{2}$ from soil air was determined by taking gas samples from stainless-steel tubes (see above). Evacuated stainless-steel cans of 0.5$2 \mathrm{~L}$ volume were connected to the tubes and slowly filled over $2-4 \mathrm{~h}$ using flow restrictors to minimize disturbances in the $\mathrm{CO}_{2}$ concentration gradient. The filled cans and tubes were closed and transported for purification of $\mathrm{CO}_{2}$ and graphite preparation at the University of California, Irvine.

Laboratory incubations of field-moist and subsequently wetted Oe/Oa and A horizons from each control and exclusion plot were conducted in 2001 and 2002. One sample of the Oe/Oa and A horizon was collected from each plot about 2 weeks before the end of throughfall exclusion in September 2001 and August 2002. In 2001, visible live roots were removed from samples while roots were not removed in 2002. As we will show in the Results section, we erroneously thought in 2002 that the live roots would die quickly and would not contribute to $\mathrm{CO}_{2}$ produced during laboratory incubations, and that the extra effort to remove them was unnecessary. We include these data to illustrate this error. The samples were incubated in airtight plastic containers at constant temperature until $\mathrm{CO}_{2}$ production was constant. Incubation jars were flushed with $\mathrm{CO}_{2}$-free air, and $\mathrm{CO}_{2}$ was allowed to accumulate to sufficient concentrations to yield enough carbon for isotopic $\left({ }^{13} \mathrm{C}\right.$ and $\left.{ }^{14} \mathrm{C}\right)$ analysis. $\mathrm{CO}_{2}$ was trapped on molecular sieve as described above for incubation of roots. Once the field-moist soil incubations had been sampled for the isotopic signature of evolved $\mathrm{CO}_{2}$, soil samples were wetted to field capacity 
over 1-2 days and then $\mathrm{CO}_{2}$ was again collected for isotopic analyses as described above.

Radiocarbon data were expressed in $\Delta^{14} \mathrm{C}$, the $\%$ deviation from the ${ }^{14} \mathrm{C} /{ }^{12} \mathrm{C}$ ratio of oxalic acid standard in 1950 , corrected to a $\delta^{13} \mathrm{C}$ value of -25 to account for mass-dependent isotopic fractionation effects (Stuiver $\&$ Polach, 1977). The precision of radiocarbon analysis including graphite preparation was $\pm 6 \%$ for modern samples analyzed at LLNL and $\pm 3-4 \%$ or samples analyzed at UC Irvine (the difference is because of measurement of ${ }^{13} \mathrm{C} /{ }^{12} \mathrm{C}$ ratios on zinc-reduced graphite by the UCI AMS). Comparison of the ${ }^{14} \mathrm{C}$ values of respired $\mathrm{CO}_{2}$ in incubations with the record of atmospheric $\Delta^{14} \mathrm{CO}_{2}$ values of the northern hemisphere and measured values from the Harvard Forest were used to determine the mean age of respired $\mathrm{CO}_{2}$ (Levin \& Hesshaimer, 2000; Trumbore 2004, personal communication). For this study, we estimated the 'mean age' of respired $\mathrm{C}$ as the number of years elapsed since atmospheric $\mathrm{CO}_{2}$ (i.e. photosynthetic products) had the ${ }^{14} \mathrm{C}$ value observed in $\mathrm{CO}_{2}$ evolved during soil incubations. Clearly, the $\mathrm{CO}_{2}$ evolved in incubations is derived from a mixture of materials of different ages, but we use this simplification for comparison.

To partition SR into $\mathrm{RR}$ and $\mathrm{CO}_{2}$ production from decay of soil organic matter (HR) we used following approach to determine the fraction of RR:

$$
\Delta^{14} \mathrm{C}_{\mathrm{SR}} \times \mathrm{SR}=\Delta^{14} \mathrm{C}_{\mathrm{RR}} \times \mathrm{RR}+\Delta^{14} \mathrm{C}_{\mathrm{HR}} \times \mathrm{HR},
$$

where $\mathrm{SR}=1, \mathrm{HR}=1-\mathrm{RR}, \Delta^{14} \mathrm{C}_{\mathrm{SR}}$ is the radiocarbon signature of $S R, \Delta^{14} C_{R R}$ is the radiocarbon signature of incubated roots, and $\Delta^{14} C_{\mathrm{HR}}$ is the radiocarbon signature of the 2001 root-free incubated $\mathrm{O}$ and $\mathrm{A}$ horizons. The $\Delta{ }^{14} C_{H R}$ value represents the integrated (fluxweighted) sources of heterotrophic respiration of both young and old C substrates under incubation conditions (2001 incubations were used for reasons described above). Included in the estimate of RR would be respiration of mycorrhizae and rhizosphere organisms present during the root incubations. The annual decline rate of $\Delta^{14} \mathrm{C}$ in atmospheric $\mathrm{CO}_{2}$ was about $5-8 \%$, which allows resolving the mean age of respired carbon within a range of \pm 1 year.

\section{Data analysis}

SR rates, $\mathrm{CO}_{2}$ concentrations of soil air and their radiocarbon values, soil temperatures, gravimetric and volumetric water contents were calculated as the means of the three replicated control and exclusion plots. Repeated measures analysis (Systat Software, 2001) was performed to test significant differences of mean $\mathrm{CO}_{2}$ fluxes between the control and exclusion plots for different periods. Exponential curves of the form $y=\beta_{0} \mathrm{e}^{\beta_{1} T}$ were applied to evaluate the relationship between SR and soil temperature, where $y$ is SR, $\beta_{0}$ and $\beta_{1}$ are fitted constants and $T\left({ }^{\circ} \mathrm{C}\right)$ is soil temperature. The relative change in SR by an increase in soil temperature of $10^{\circ} \mathrm{C}$ was calculated as $Q_{10}=\mathrm{e}^{10 \times \beta_{1}}$. Linear regressions were performed (Systat Software, 2001) to evaluate the relationships between the differences of the exclusion and control plots in SR and water contents of the $\mathrm{Oi}, \mathrm{Oe} / \mathrm{Oa}$, and A horizons.

We used an empirical model approach (Borken et al., 1999) to estimate SR $\left(\mathrm{mg} \mathrm{Cm}^{-2} \mathrm{~h}^{-1}\right)$ during growing seasons as a function of soil temperature and water content of the Oe/Oa horizon:

$$
\mathrm{SR}=A \mathrm{e}^{(-E / R T)}(1+b \mathrm{WC}),
$$

where $A$ is an Arrhenius constant (dimensionless), $E$ is the apparent activation energy $\left(\mathrm{kJ} \mathrm{mol}^{-1}\right), R$ is the universal gas constant $\left(0.008314 \mathrm{~kJ} \mathrm{~mol}^{-1} \mathrm{~K}^{-1}\right), T$ is the soil temperature at $10 \mathrm{~cm}$ depth $(\mathrm{K}), b$ is an empirical fitting parameter that describes the influence of soil water content on SR, and WC is the water content $\left(\mathrm{g} \mathrm{g}^{-1}\right)$ of the Oe/Oa horizon. This model cannot fit a decrease in SR as a result of $\mathrm{O}_{2}$ limitation at high water contents. However, we did not observe such a limitation at our well-drained study site.

\section{Results}

$S R$, temperature, water contents and precipitation in the control plots

In the control plots, SR followed in general the seasonal pattern in soil temperature with the highest rates of $>200 \mathrm{mg} \mathrm{C} \mathrm{m}^{-2} \mathrm{~h}^{-1}$ from July to August and the lowest rates $<40 \mathrm{mg} \mathrm{C} \mathrm{m}^{-2} \mathrm{~h}^{-1}$ from December to April (Fig. 1). Overall, soil temperature explained $88 \%$ of the seasonal variation in SR of the control plot and a $Q_{10}$ of 3.9 indicated a strong temperature sensitivity of SR.

$\mathrm{SR}$ also responded to changes in soil water contents in the $\mathrm{O}$ horizon and mineral soil (Fig. 1c, d). Gravimetric water contents of the Oi horizon varied form 0.01 to $2.17 \mathrm{~g} \mathrm{~g}^{-1}$ and showed strong fluctuations because of drying and wetting cycles (Fig. 1c). The intensively rooted Oe/Oa horizon was also affected by drying, but to lesser extremes, as indicated by water contents ranging from 0.64 and $2.64 \mathrm{gg}^{-1}$ (Fig. 1d). The rapid increases in water content corresponded well with rain events (Fig. 1f), suggesting that large amounts of rainwater passed into the Oe/Oa horizon. Moreover, the capacity of the Oe/Oa horizon to store larger amounts of throughfall water was variable, depending on previous moisture conditions. During periods of several days between throughfall events, gravimetric water 


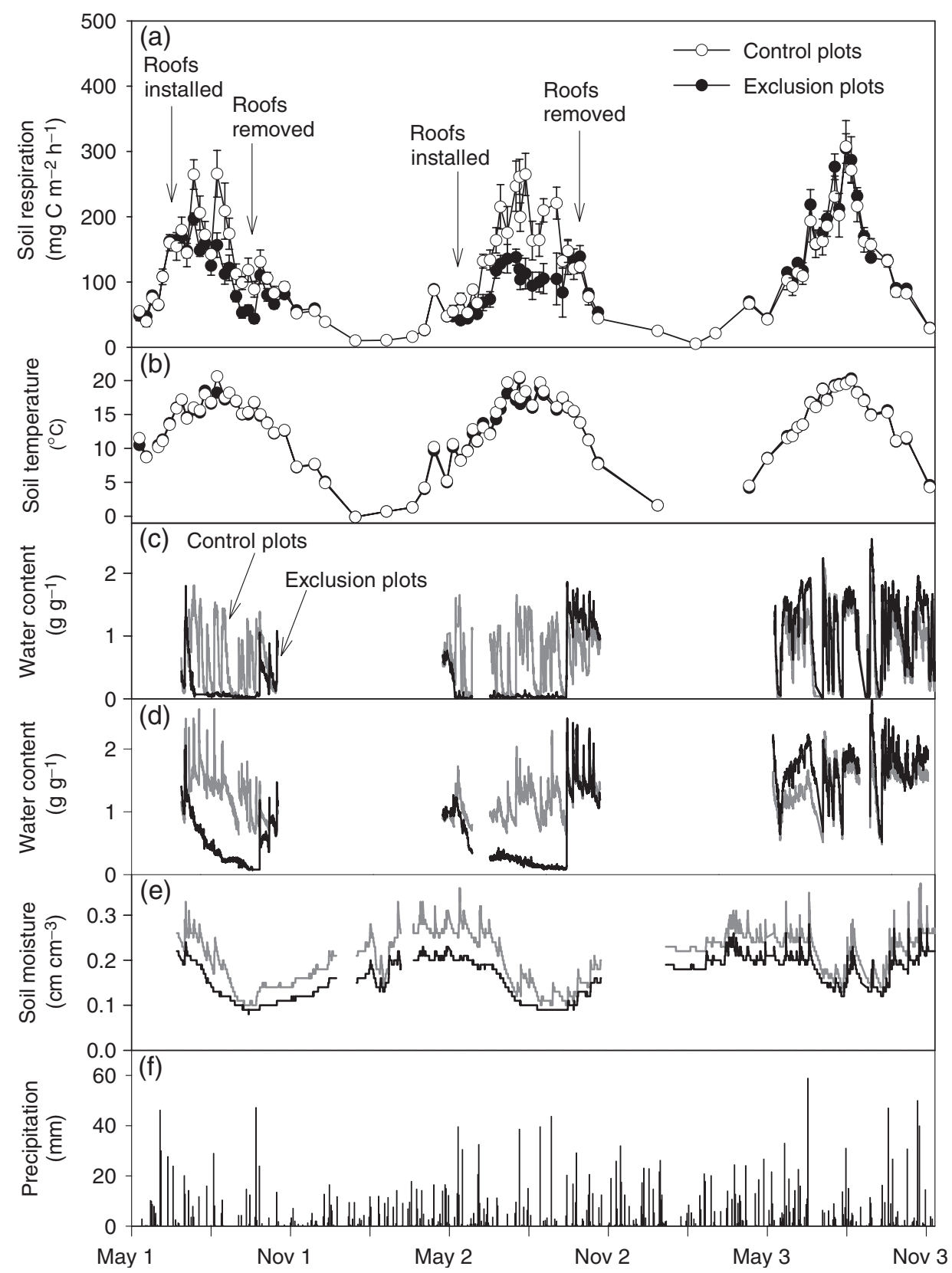

Fig. 1 (a) Soil respiration rates, (b) soil temperature at $10 \mathrm{~cm}$ depth, (c) gravimetric water content in the Oi horizon and (d) the Oe/Oa horizon, (e) volumetric soil water content at $5 \mathrm{~cm}$ mineral soil depth, and (f) daily precipitation in the control and exclusion plots of a mixed deciduous forest at the Harvard Forest from June 2001 to November 2003. Error bars represent the standard error of the means $(n=3)$.

contents of the Oe/Oa horizon remained below $1.7 \mathrm{gg}^{-1}$.

Volumetric water contents of the mineral soil at $5 \mathrm{~cm}$ depth followed a seasonal pattern with maximum values in spring after snow melt and minimum values in late August to mid-September (Fig. 1e). We observed a strong decrease in liquid water content estimated by TDR technology at $5 \mathrm{~cm}$ depth in February 2002, which was related to frost at this depth. The A horizon $(5 \mathrm{~cm}$ depth) showed generally higher water contents $(0.10-$ $0.37 \mathrm{~cm}^{3} \mathrm{~cm}^{-3}$ ) and responded more intensively to rain events than the B horizon (not shown). A drop in volumetric water contents to $0.10 \mathrm{~cm}^{3} \mathrm{~cm}^{-3}$ occurred in both horizons, suggesting that water became a limiting factor for biological processes in August/September 2001 and 2002. Because of higher precipitation in 2003, 
soil water content did not fall below $0.13 \mathrm{~cm}^{3} \mathrm{~cm}^{-3}$ in the summer of 2003.

In total, we observed 10 periods of 7 days or more without precipitation and with water contents $<0.10 \mathrm{~g} \mathrm{~g}^{-1}$ in the Oi horizon of the control plots during the three growing seasons (Fig. 1c,f). The longest drought period without any precipitation occurred over 18 days from mid- to end August of 2001 (Fig. 1f). SR dropped by 122 and $151 \mathrm{mgC} \mathrm{m}^{-2} \mathrm{~h}^{-1}$ in the control plots during two periods with high temperatures and low precipitation in July and August/September of 2001. A clear decrease in SR by $89 \mathrm{mg} \mathrm{C} \mathrm{m}^{-2} \mathrm{~h}^{-1}$ related to natural soil drought was observed within 1 week in early September 2002. Moreover, SR decreased to a lesser extent during other drought periods.

SR markedly peaked at five occasions during the growing seasons, which were partly explained by wetting of dry soil (Fig. 1). The week-to-week increases in SR of 116 and $123 \mathrm{mg} \mathrm{C} \mathrm{m}^{-2} \mathrm{~h}^{-1}$ in July and August 2001 were the result of wetting events.

In addition to wetting events, high SR rates were also related to the development of fruiting bodies from a fungus species at our site. We first noticed one large fruiting body growing in one collar, which produced one of the highest fluxes that we have ever measured (431 $\mathrm{mg} \mathrm{C} \mathrm{m}^{-2} \mathrm{~h}^{-1}$ on August 7, 2001). In July 2002, we set up four additional chambers, each including one fruiting body of Russula spec. and again measured high mean $\mathrm{CO}_{2}$ fluxes of $511 \pm 52 \mathrm{mg} \mathrm{C} \mathrm{m}^{-2} \mathrm{~h}^{-1}$ as compared with chambers from the control plots $\left(265 \pm 65 \mathrm{mg} \mathrm{C} \mathrm{m}^{-2} \mathrm{~h}^{-1}\right)$ without fruiting bodies. Belowground mycelium of these fungi that are not visible may also contribute to the large fluxes occasionally measured in some of the collars without fruiting bodies.

Comparing the growing seasons, mean SR rates of $135,143 \mathrm{mg}$ and $154 \mathrm{mg} \mathrm{C} \mathrm{m}^{-2} \mathrm{~h}^{-1}$ in 2001, 2002 and 2003 were not statistically different. However, this trend of increasing mean $\mathrm{CO}_{2}$ fluxes across years coincided with a similar increase in the amount of precipitation
$(461 \mathrm{~mm}, 583 \mathrm{~mm}$ and $717 \mathrm{~mm}$ during the growing seasons of 2001, 2002 and 2003, respectively).

\section{Effect of throughfall exclusion on $S R$}

Before the treatment in 2001 and 2002, SR rates of the control and exclusion plots were not different (Fig. 1a, Table 2). The exclusion of 168 and $344 \mathrm{~mm}$ throughfall significantly $(P<0.05)$ reduced cumulative SR by 101 and $210 \mathrm{~g} \mathrm{C} \mathrm{m}^{-2}$ in 2001 and 2002, respectively (Table 2). In 2001, SR in the exclusion plots declined from 197 to $44 \mathrm{mg} \mathrm{C} \mathrm{m}^{-2} \mathrm{~h}^{-1}$ over 84 days, whereas soil temperature showed little variation $\left(15.1-20.6^{\circ} \mathrm{C}\right)$ during this period. A different pattern was found in 2002 as SR increased moderately with soil temperature from early May to mid-July. Afterwards, SR decreased in the exclusion plots from 138 to only $84 \mathrm{mgC} \mathrm{m}^{-2} \mathrm{~h}^{-1}$ as compared with $44 \mathrm{mg} \mathrm{C} \mathrm{m}^{-2} \mathrm{~h}^{-1}$ in 2001.

SR increased by $66 \mathrm{mg} \mathrm{C} \mathrm{m}^{-2} \mathrm{~h}^{-1}$ in 2001 and by $53 \mathrm{mgC} \mathrm{m}^{-2} \mathrm{~h}^{-1}$ in 2002 after the roof panels were removed and $65 \mathrm{~mm}$ (in 2001) and $22 \mathrm{~mm}$ throughfall (in 2002) wetted the soil. The responses of SR to these wetting events were rather small, but similar to the $\mathrm{CO}_{2}$ peaks observed in the control plots following soil wettings in September of 2001 and 2002.

Soil temperature explained $73 \%$ of the temporal variation in SR in the exclusion plots, considering all measurements of these plots from winter to summer in 2001 and 2002. The $Q_{10}$ of 3.0 is lower than for the control plots (3.9) but still indicated a strong wintersummer temperature dependency of SR. During the simulated summer drought periods, however, SR was not correlated with soil temperature from 12.5 to $20.3^{\circ} \mathrm{C}$ $\left(r^{2}=0.09\right)$.

Water content of the Oi horizon dropped rapidly after the installation of the roof panels and remained below $0.10 \mathrm{gg}^{-1}$ throughout the treatment periods in both years (Fig. 1c). The Oe/Oa horizon also showed a clear treatment effect but the drying process lasted nearly over the entire period (Fig. 1d). In contrast to the Oe/Oa

Table 2 Mean soil respiration rates ( $\pm \mathrm{SE}$ ) and differences in cumulative $\mathrm{CO}_{2}$ fluxes (exclusion plots-control plots) by treatment and season using manual chambers from 2001 to 2003

\begin{tabular}{|c|c|c|c|c|}
\hline \multirow[b]{2}{*}{ Period } & \multirow[b]{2}{*}{ No. of days } & Control plots & Drought plots & Difference \\
\hline & & \multicolumn{2}{|l|}{$\left(\mathrm{mgC} \mathrm{m}{ }^{-2} \mathrm{~h}^{-1}\right)$} & $\left(\mathrm{gC} \mathrm{m}^{-2}\right)$ \\
\hline Pretreatment May 9-July 1, 2001 & 54 & $105(10)$ & $107(1)$ & +2 \\
\hline Throughfall exclusion July 2-September 24, 2001 & 84 & $166(19)$ & $117(5)$ & $-101^{*}$ \\
\hline No treatment September 25, 2001-May 7, 2002 & 227 & $58(4)$ & $53(3)$ & -13 \\
\hline Throughfall exclusion May 8-September 10, 2002 & 127 & $159(17)$ & $91(11)$ & $-210^{*}$ \\
\hline Posttreatment September 11, 2002-November 10, 2003 & 424 & $244(23)$ & $258(14)$ & $+46^{*}$ \\
\hline Total & 916 & $131(13)$ & $110(5)$ & -276 \\
\hline
\end{tabular}

Significant differences are indicated by ${ }^{*}$ at $\alpha=0.05$. 
horizon of the control plots, water contents of the exclusion plots reached minimum values of $0.07 \mathrm{~g} \mathrm{~g}^{-1}$. The $\mathrm{Oi}$ and $\mathrm{Oe} / \mathrm{Oa}$ horizons responded quickly to wetting after the removal of the roof panels. Throughfall exclusion had apparently no significant effect on volumetric water contents of the mineral soil at 5 and $32 \mathrm{~cm}$ depth (not shown) during periods between throughfall events (Fig. 1d), and the $5 \mathrm{~cm}$ depth showed no or only small increases in water content after rain events as compared with the control plots. Overall, water contents ranged between 0.08 and $0.24 \mathrm{~cm}^{3} \mathrm{~cm}^{-3}$ at the $5 \mathrm{~cm}$ depth and from 0.09 to $0.28 \mathrm{~cm}^{3} \mathrm{~cm}^{-3}$ at the $32 \mathrm{~cm}$ depth in 2001 and 2002.

SR was statistically different $(P<0.003)$ between the control and exclusion plots during the posttreatment period from September 2002 to November 2003 (Table 2). The difference in cumulative interpolated $S R$ was $46 \mathrm{~g} \mathrm{C} \mathrm{m}^{-2}$ for the posttreatment period and $-276 \mathrm{C} \mathrm{m}^{-2}$ for the total period, indicating that subsequent wetting of soil did not compensate the inhibitory effects of two summers of throughfall exclusion treatment on SR. However, it is possible that some enhanced respiration may have occurred in the exclusion plots during the wet period of winter and spring 2003, when we sampled infrequently.

\section{Hourly changes in SR}

In the control plots, SR generally followed the diurnal trend in soil temperature (Fig. 2a, b), except when the Oi horizon was dry, such as JD 185-190 (Fig. 2c). Similarly, although the diurnal variation in soil temperature was slightly greater in the exclusion plots compared with the control plot (Fig. 2b), presumably because of less thermal mass in the dry mineral soil and $\mathrm{O}$ horizon, diel variation in SR was very weak in the exclusion plot (Fig. 2a). SR responded immediately to wetting events in the control plots as indicated by increasing water contents in the Oi horizon and by precipitation (Fig. 2e). The $\mathrm{CO}_{2}$ pulse lasted 1-5 days depending on the amount of precipitation and the water content in the Oi horizon. In contrast to the $\mathrm{Oi}$, the water content of the A horizon increased only on Julian days 178-180 with $19.3 \mathrm{~mm}$ precipitation while small amounts of $<5 \mathrm{~mm}$ did not affect the water content of the A horizon (Fig. 2d).

In order to estimate the magnitude of postwetting pulses of $\mathrm{CO}_{2}$ efflux relative to seasonal sums in the control plot, a 'nonwetting' estimate was derived for a 4 -week period when automated chambers were operating during the growing season. Linear regressions between SR rates in exclusion and control plots were

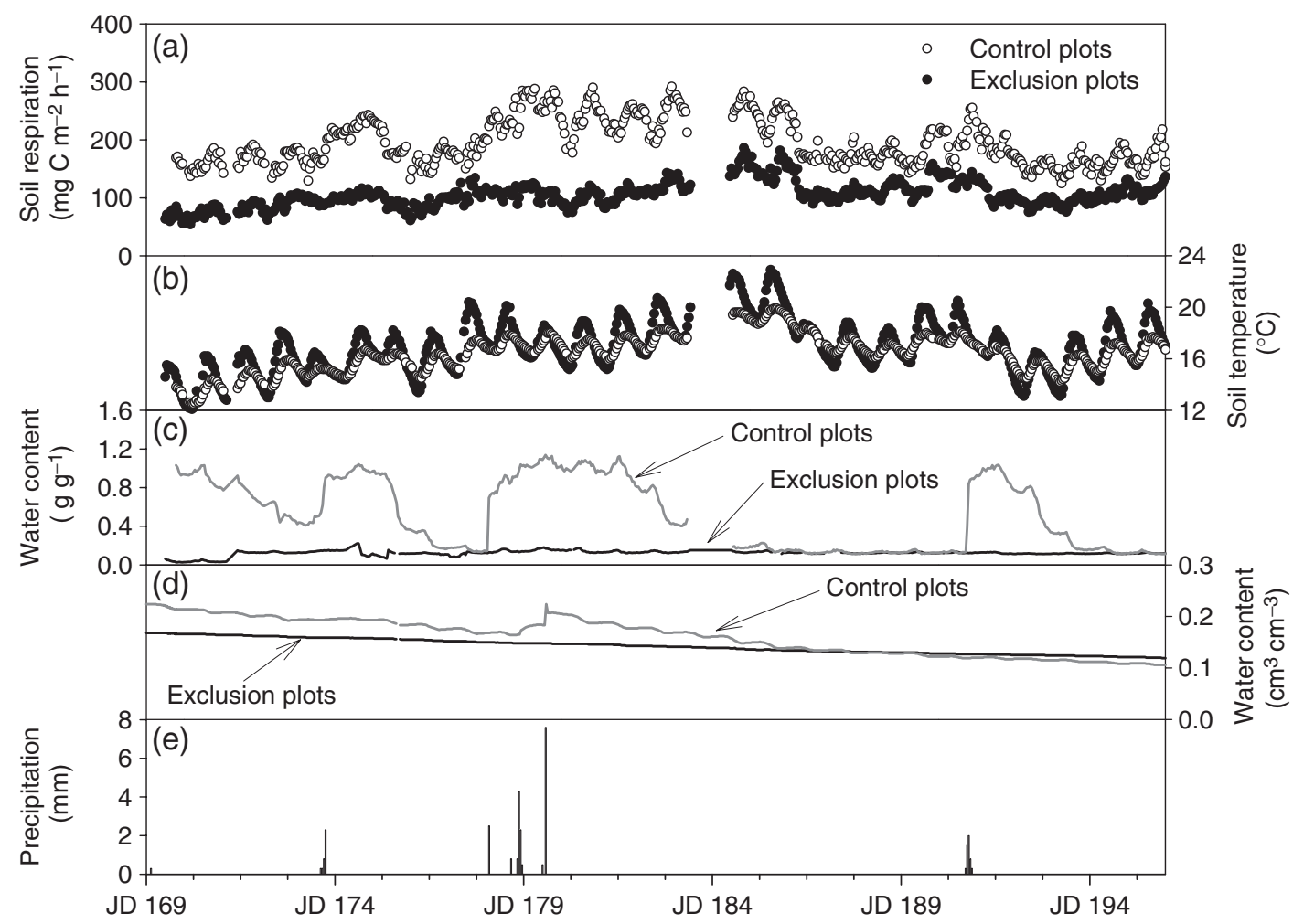

Fig. 2 (a) Hourly changes in soil respiration (b) soil temperature at $10 \mathrm{~cm}$ depth, (c) gravimetric water content in the Oi horizon, (d) volumetric soil water content at $5 \mathrm{~cm}$ mineral soil depth, and (e) daily precipitation in the control and exclusion plots over 28 days in June/July 2002. Values represent the mean of three replications. 


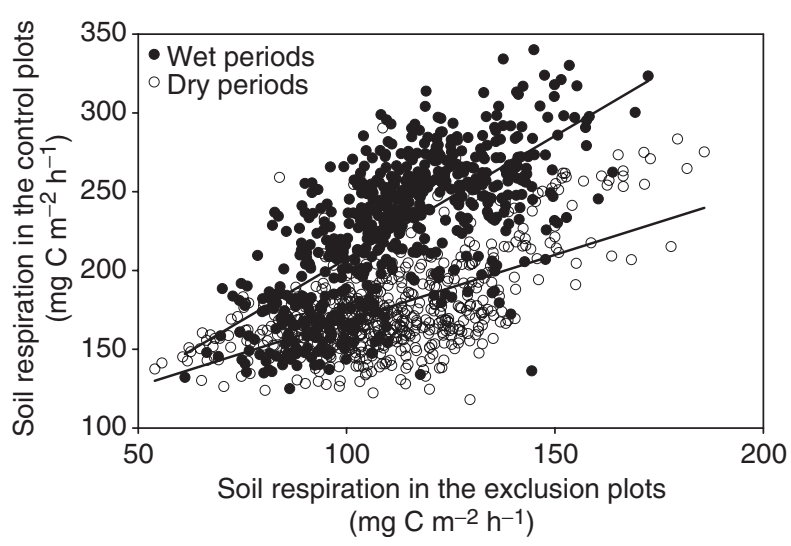

Fig. 3 Relationship between hourly measured soil respiration rates of the control and exclusion plots from June to September 2002. The data were separated into 'dry' periods and 'wet' periods beginning with precipitation and ending when water content of the Oi horizon dropped below $0.4 \mathrm{gg}^{-1}$. Linear regressions were performed for the wet period $\left(y=1.56 x+51.6, r^{2}=0.47\right)$ and the dry period $(y=0.83 x+85.0$, $\left.r^{2}=0.34\right)$.

performed for periods with water contents $<0.4 \mathrm{~g} \mathrm{~g}^{-1}$ and $>0.4 \mathrm{~g} \mathrm{~g}^{-1}$ in the Oi horizon (Fig. 3). Based on the regression for water contents $<0.4 \mathrm{gg}^{-1}$, we estimated what the respiration rate would have been in the control plots had rainfall events not occurred and had prerain rates in the control plots responded only to the same gradual seasonal warming experience by the exclusion plots. The difference between the estimated and measured SR rates in the control plots was attributed to wetting events and amounted to $29 \mathrm{~g} \mathrm{C} \mathrm{m}^{-2}$ within the 4 -week period, which is about $24 \%$ of the measured flux $\left(121 \mathrm{~g} \mathrm{C} \mathrm{m}^{-2}\right)$ in the control plots.

Cumulative SR rate for this period was $121 \mathrm{~g} \mathrm{C} \mathrm{m}^{-2}$ using automated and $111 \mathrm{~g} \mathrm{C} \mathrm{m}^{-2}$ using manual chambers, indicating that weekly measurements may have under estimated SR at our site. This difference between manual and automated chambers is small, considering that manual chambers are sums of interpolations whereas the autochamber estimates are sums of hourly measurements.

\section{Relationships between SR and soil moisture}

Mean soil temperatures of the exclusion plots were 0.2 and $0.4^{\circ} \mathrm{C}$ lower during the treatment periods in 2001 and 2002, indicating that the roof construction had only little effect on soil temperature. Hence, the differences in SR between the control and exclusion plots can be attributed to the differences in soil water contents. The effects of throughfall exclusion on SR were best explained by the differences in water contents of the $\mathrm{Oi}$ horizon $\left(r^{2}=0.74, \quad P<0.01\right)$ and $\mathrm{Oe} / \mathrm{Oa}$ horizon $\left(r^{2}=0.67, P<0.01\right)$ (Fig. 4a, b). By contrast, the water contents of the A horizon showed absolutely no relationship $\left(r^{2}=0.001\right)$ to the differences in SR (Fig. 4c), indicating that experimental drought mainly reduced $\mathrm{CO}_{2}$ production in the $\mathrm{O}$ horizon.

We used an empirical model to predict SR in the control and exclusion plots using soil temperature and soil water content of the Oe/Oa horizon during the growing seasons. The model explained $85 \%$ of the variance in SR combining data of the control and exclusion plots. The fitted parameters were $A=1.76 \times 10^{16}, E=79.3$, and $b=0.69$. The model fit and model parameters were not significantly different using only data from the control plots $\left(A=9.31 \times 10^{15}\right.$, $E=78.0$, and $b=0.83, r^{2}=0.82$ ). According to the model results, the importance of soil water content increases with increasing soil temperature (Fig. 5), indicating that changes in soil moisture at high soil temperature have large effects on SR. Soil temperature as a single independent variable explained only $60 \%$ of the variance in SR.

\section{Radiocarbon content of air, SR and incubated fine roots}

The $\Delta^{14} \mathrm{CO}_{2}$ signature of ambient air ranged from $67 \%$ to $79 \%$. Similar signatures of $69-80 \%$ were found for $\mathrm{CO}_{2}$ from incubated fine roots, indicating that roots respired recently fixed carbon from June to September 2002 (Fig. 6). The $\Delta^{14} \mathrm{CO}_{2}$ signatures of SR were nearly identical (105\% and 106\%) in control and exclusion plots before the beginning of the treatment on July 2, 2001. With one exception, the $\Delta^{14} \mathrm{CO}_{2}$ signature of SR varied between $85 \%$ and $107 \%$ in the control plots and between $54 \%$ and $108 \%$ in the exclusion plots over the entire experimental period. The exception occurred on August 1, 2002, when $\mathrm{CO}_{2}$ enriched in $\Delta^{14} \mathrm{C}$ was released in the exclusion plots (263\%) and the control plots $(141 \%)$. This occurred simultaneously with the development of numerous fruiting bodies throughout the study area of a fungus species that was not determined. One large fruiting body was growing in one collar which exhibited the highest radiocarbon signature $(422 \%)$ and resulted in a large standard deviation (Fig. 6). High radiocarbon contents were also detected for $\mathrm{CO}_{2}$ fluxes from chambers without fruiting bodies in both the exclusion and control plots on this date, perhaps indicating that the belowground mycelium of this fungus was utilizing carbon that is more enriched in $\Delta^{14} \mathrm{C}$ than recent photosynthetic products. Only decomposition of woody detritus (coarse roots or branches) formed from photosynthate originally fixed $10-20$ years ago is likely to produce ${ }^{14} \mathrm{C}$ values this high (Gaudinski et al., 2000). 

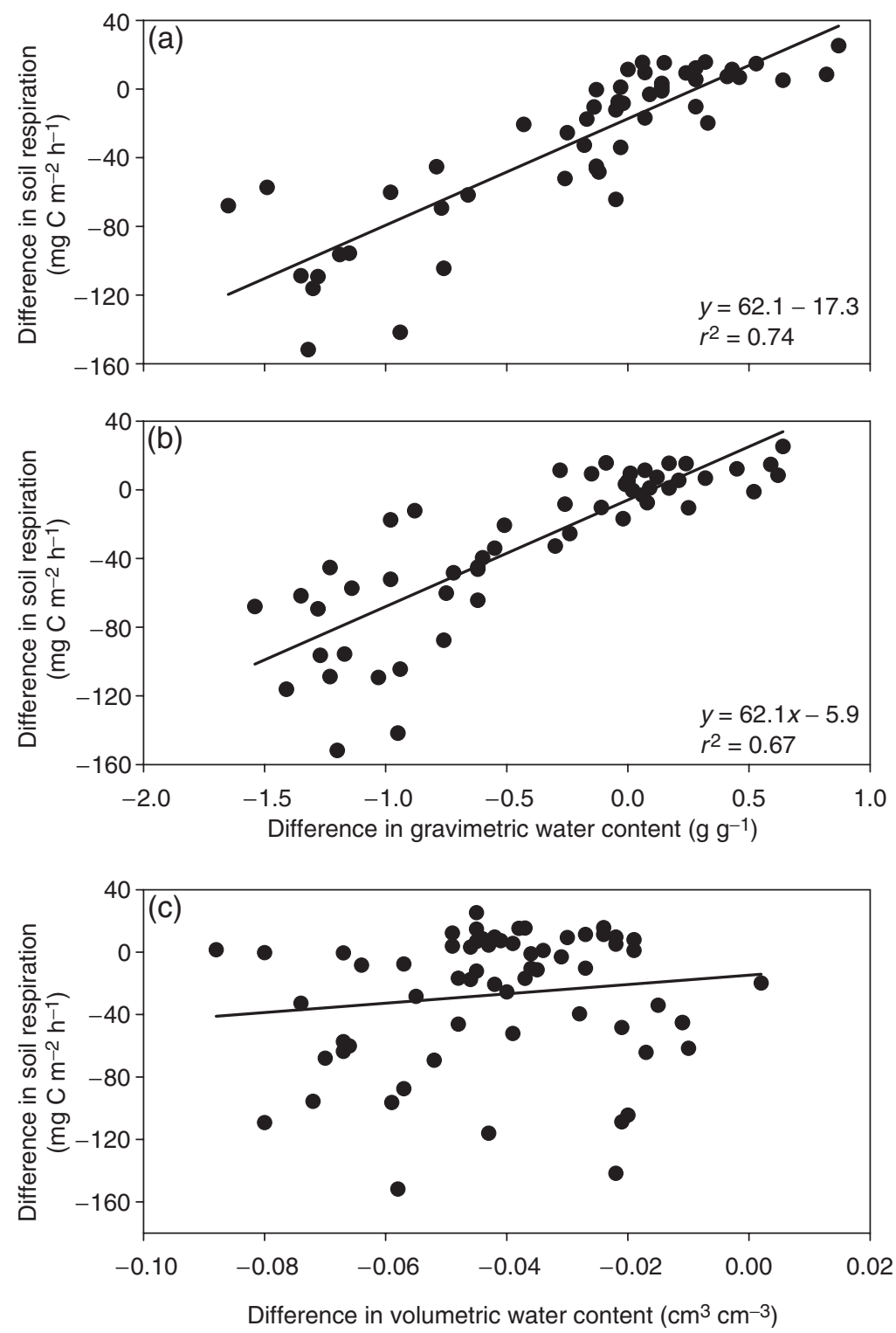

Fig. 4 Relationship of the differences (exclusion plots-control plots) in soil respiration and the differences in soil moisture of (a) the Oi horizon, (b) the Oe/Oa horizon and the (c) the A horizon between the exclusion and the control plots.

A trend towards lower $\Delta^{14} \mathrm{CO}_{2}$ values in the exclusion plots as the summer progressed in 2002 suggests that the relative contribution from decomposition of older organic matter may have gradually decreased during the exclusion treatment. In other words, RR was less affected by the exclusion treatment than was the decay of older SOM.

When the top soil was thoroughly wetted with $22 \mathrm{~mm}$ throughfall after the removal of roof panels in September 2002, the ${ }^{14} \mathrm{CO}_{2}$ signature dropped to $54 \%$ which is lower than the ${ }^{14} \mathrm{CO}_{2}$ signature of the atmosphere and roots (both $72 \%$ ). Hence, wetting of soil caused a strong release of prebomb carbon that diluted the ${ }^{14} \mathrm{CO}_{2}$ signature of modern fixed carbon in the exclusion plots.
In 2003, when no roofs were in place, the ${ }^{14} \mathrm{CO}_{2}$ signature of SR decreased from about $108 \%$ to less than $90 \%$ in both the control and exclusion plots, indicating that the ratio of RR to the decay of SOM increased during the growing season in 2003. Moreover, the exclusion treatments in 2001 and 2002 did not affect the ${ }^{14} \mathrm{CO}_{2}$ signature of SR in 2003.

\section{${ }^{14} \mathrm{CO}_{2}$ signature of soil air and its relationship to $\mathrm{CO}_{2}$ concentration}

In both the control and exclusion plots, the ${ }^{14} \mathrm{CO}_{2}$ signature of soil air varied between $77 \%$ and $284 \%$ in the $\mathrm{A}$ and $\mathrm{B}$ horizon and between $87 \%$ and $106 \%$ at 
$53 \mathrm{~cm}$, the transition from the B to the C horizon (Fig. 7). We observed almost no dynamic and no relationship between $\Delta{ }^{14} \mathrm{CO}_{2}$ values and $\mathrm{CO}_{2}$ concentration at the lowest depth, which may be explained by RR and decomposition of relative young root litter as the predominant $\mathrm{CO}_{2}$ sources at this depth.

The ${ }^{14} \mathrm{CO}_{2}$ signature of soil air increased with decreasing $\mathrm{CO}_{2}$ concentration in the $\mathrm{A}$ and $\mathrm{B}$ horizon. Low $\mathrm{CO}_{2}$ concentrations and high radiocarbon values generally occurred under both natural and experimental drought conditions, whereas high concentrations and low radiocarbon values occurred when the soil was relatively wet. As already noted, SR rates also declined

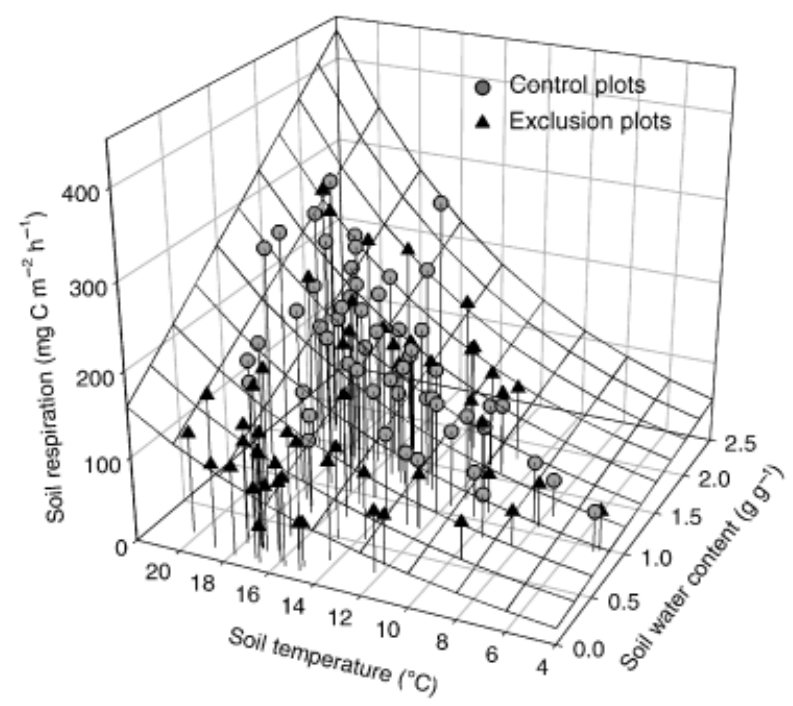

Fig. 5 Mean soil respiration rates of the control and exclusion plots as a function of soil temperature and water content in the Oe/Oa horizon during the growing seasons in 2001-2003 $(n=112)$ during drought conditions, but in contrast to mineral soil concentrations, the radiocarbon values of $\mathrm{CO}_{2}$ emitted from the soil surface were either relatively constant or showed a trend toward declining values with drought. Therefore, most of this radiocarbon-poor $\mathrm{CO}_{2}$ emitted from the soil surface must be produced above the A horizon, because our measurements within the A horizon clearly show higher radiocarbon values. The high $\Delta^{14} \mathrm{CO}_{2}$ values observed in the soil atmosphere at the $\mathrm{A}$ and $\mathrm{B}$ horizon in the mineral soil are interesting, but apparently are usually not quantitatively important with respect to SR fluxes.

\section{${ }^{14} \mathrm{CO}_{2}$ signature of incubated $\mathrm{O}$ and $A$ horizons and partitioning of $S R$}

The exclusion treatment reduced the ${ }^{14} \mathrm{CO}_{2}$ signature of incubated soil samples of the $\mathrm{O}$ and $\mathrm{A}$ horizons in both years (Table 3). Because of large variations in the ${ }^{14} \mathrm{CO}_{2}$

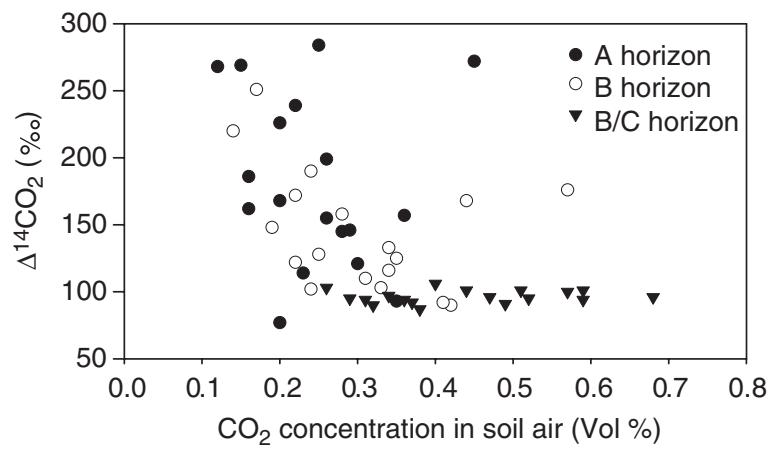

Fig. 7 Mean radiocarbon signature of $\mathrm{CO}_{2}$ from soil air collected at three horizons in the control and the exclusion plots as a function of $\mathrm{CO}_{2}$ concentration from 2001 and 2002.

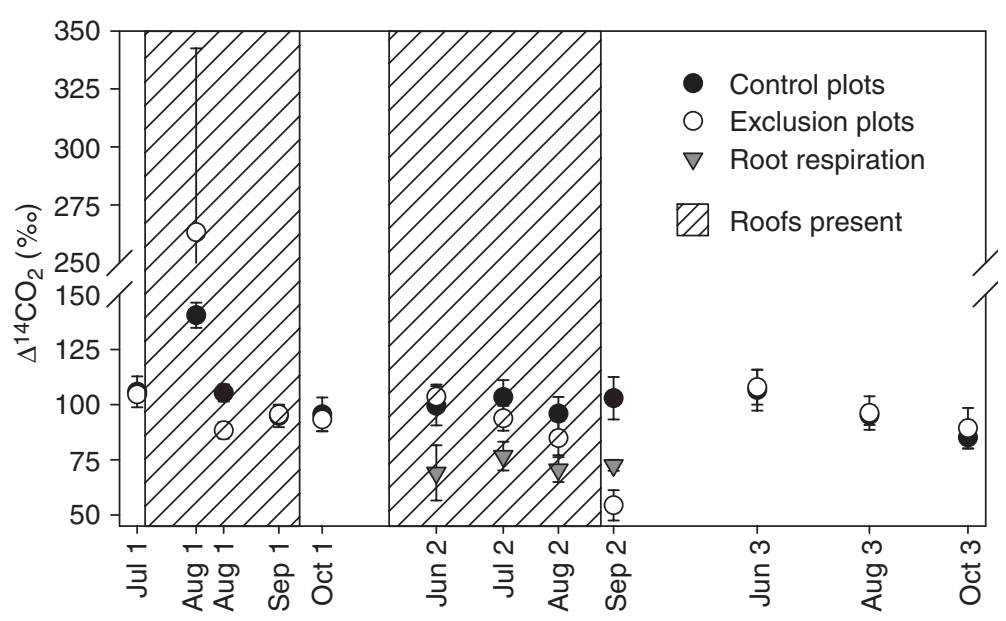

Fig. 6 Mean radiocarbon signature of $\mathrm{CO}_{2}$ from soil respiration in the control and the exclusion plots during the growing seasons in 2001-2003. Error bars represent the standard deviation of the mean $(n=3)$. 
Table 3 Mean ( \pm SE) radiocarbon signature of released $\mathrm{CO}_{2}$ and gravimetric water contents during incubation of field moist and subsequently wetted $\mathrm{O}$ and $\mathrm{A}$ horizons from the control and exclusion plots at the Harvard forests in 2001 and 2002

\begin{tabular}{|c|c|c|c|c|c|c|c|c|c|}
\hline \multirow{2}{*}{$\frac{\text { Horizons }}{\text { O horizon }}$} & \multirow{2}{*}{$\begin{array}{l}\text { Wetting } \\
\text { Field moist }\end{array}$} & \multicolumn{2}{|c|}{$\begin{array}{l}2001 \\
\text { Control Exclusion } \\
\Delta^{14} \mathrm{CO}_{2}(\%)\end{array}$} & \multicolumn{2}{|c|}{$\begin{array}{l}\text { Control Exclusion } \\
\text { Water content }\left(\mathrm{gg}^{-1}\right)\end{array}$} & \multicolumn{2}{|c|}{$\begin{array}{l}2002 \\
\text { Control } \\
\Delta^{14} \mathrm{CO}_{2}(\%)\end{array}$} & \multicolumn{2}{|c|}{$\begin{array}{l}\text { Control Exclusion } \\
\text { Water content }\left(\mathrm{g} \mathrm{g}^{-1}\right)\end{array}$} \\
\hline & & $148(9)$ & 127 (15) & $0.88(0.13)$ & $0.38(0.12)$ & $85.6(7.0)$ & $68.0(6.0)$ & $1.01(0.09)$ & $0.68(0.05)$ \\
\hline & Wetted in lab & - & 160 & - & 1.07 & $117.8(5.5)$ & $110.7(8.9)$ & $2.18(0.33)$ & $1.53(0.29)$ \\
\hline \multirow[t]{2}{*}{ A horizon } & Field moist & $146(13)$ & 112 (17) & $0.28(0.04)$ & $0.21(0.02)$ & 75.7 (5.7) & $46.4(3.7)$ & $0.30(0.00)$ & $0.18(0.02)$ \\
\hline & Wetted in lab & - & $104(4)$ & - & 0.41 & 75.9 (2.6) & 118.9 (1.5) & $0.80(0.11)$ & $0.65(0.00)$ \\
\hline
\end{tabular}

Live roots were removed from samples in 2001, but not in 2002 . We suspect lowered ${ }^{14} \mathrm{C}$ values in 2002 are because of remnant respired C from live roots and have used 2001 values to calculate fraction of rhizosphere respiration for all years of the experiment.

signature, the drought effect was only significant for the A horizon in 2002. The low ${ }^{14} \mathrm{CO}_{2}$ value of $46 \%$ for the A horizon from the exclusion plots shows that prebomb carbon was released during incubation.

With one exception, wetting of $\mathrm{O}$ and $\mathrm{A}$ horizon from the control and exclusion plots increased the radiocarbon content of respired $\mathrm{CO}_{2}$ indicating that the portion of $\mathrm{CO}_{2}$ from 'older' SOM increased. In 2001, the wetted A horizon from the exclusion plot had a lower radiocarbon content than the field-moist sample. However, the variation in the ${ }^{14} \mathrm{CO}_{2}$ signature was particularly large in 2001 when live roots were removed from samples. The removal of live roots had a large effect on the ${ }^{14} \mathrm{CO}_{2}$ signature as indicated by about $60-$ $70 \%$ higher values for the field-moist samples without roots. Apparently, the rhizosphere (i.e. live root cells and/or heterotrophic microorganisms in the rhizosphere) still produced $\mathrm{CO}_{2}$ and diluted the ${ }^{14} \mathrm{CO}_{2}$ signal from the decay of SOM in 2002.

The results of the 2002 incubation could not be used to partition SR because the ${ }^{14} \mathrm{CO}_{2}$ signatures of the $\mathrm{O}$ and A horizons were below the signatures of SR. Thus, we calculated an endmember for the decay of SOM of 139\% using the ${ }^{14} \mathrm{CO}_{2}$ signatures (Table 3), the $\mathrm{CO}_{2}$ production rates (not shown) and the total amount of the $\mathrm{O}$ and $\mathrm{A}$ horizons (Table 1) from both plots from 2001. However, we did not attempt to partition SR for the fungus derived peak on August 1, 2001, or after wetting of dry soil on September 17, 2002, because the assumption that the heterotrophic endmember had a ${ }^{14} \mathrm{CO}_{2}$ signature of $139 \%$ was probably not valid under those special circumstances. We used the atmospheric ${ }^{14} \mathrm{CO}_{2}$ signature as an endmember of $\mathrm{RR}$, because the ${ }^{14} \mathrm{CO}_{2}$ signatures of the atmosphere and incubated roots were not different.

The relative portion of RR generally increased during the growing seasons and ranged between $43 \%$ and $71 \%$ in the control plots (Fig. 8a) and between $41 \%$ and $80 \%$ in the exclusion plots (Fig. 8b). Moreover, the partitioning of SR revealed that the exclusion treatment had a greater negative effect on the decay of SOM than on RR (Fig. 8c). By contrast, SOM respiration slightly increased in the exclusion plots during the posttreatment period in 2003.

\section{Discussion}

This experiment clearly showed that extended summer drought decreases SR at the Harvard Forest. Exclusion of 168 and $344 \mathrm{~mm}$ throughfall reduced cumulative SR by $101 \mathrm{~g} \mathrm{C} \mathrm{m}^{-2}$ in 2001 and by $210 \mathrm{~g} \mathrm{C} \mathrm{m}^{-2}$ in 2002 , which is about $15-30 \%$ of mean annual SR rate at the well-drained sites (Savage \& Davidson, 2001). Because both control and treatment plots experienced the same temperature regime, these effects can be attributed primarily to lower soil water content.

The effect of throughfall exclusion on SR was best explained by the differences in water content of the Oi and Oe/Oa horizons between the exclusion and control plots, suggesting that the exclusion treatment caused a decrease in respiration mainly in the $\mathrm{O}$ horizon. By contrast, the differences in volumetric water content of the A horizon could not explain the decrease in SR. This result does not mean that respiration in the A horizon is unimportant or that it does not vary seasonally with variation in temperature and water content. A previous analysis of SR and temperature data revealed that the residuals of an exponential temperature function were correlated with water contents in both the $\mathrm{A}$ and $\mathrm{O}$ horizons of the control plots at our site (Borken et al., 2003). However, the present results from the throughfall exclusion experiment demonstrate a more frequent and larger effect on the $\mathrm{O}$ horizon.

The amount of throughfall from June to August of $230 \mathrm{~mm}$ in 2001 and $250 \mathrm{~mm}$ in 2002 was less than average evapotranspiration of approximately $350 \mathrm{~mm}$ during these periods (Greenland, 1996). Therefore, the PAW of $109 \mathrm{~mm}$ that can be stored in the soil down to $53 \mathrm{~cm}$ depth must have been almost completely used in August/September of 2001 and 2002. Taking an 


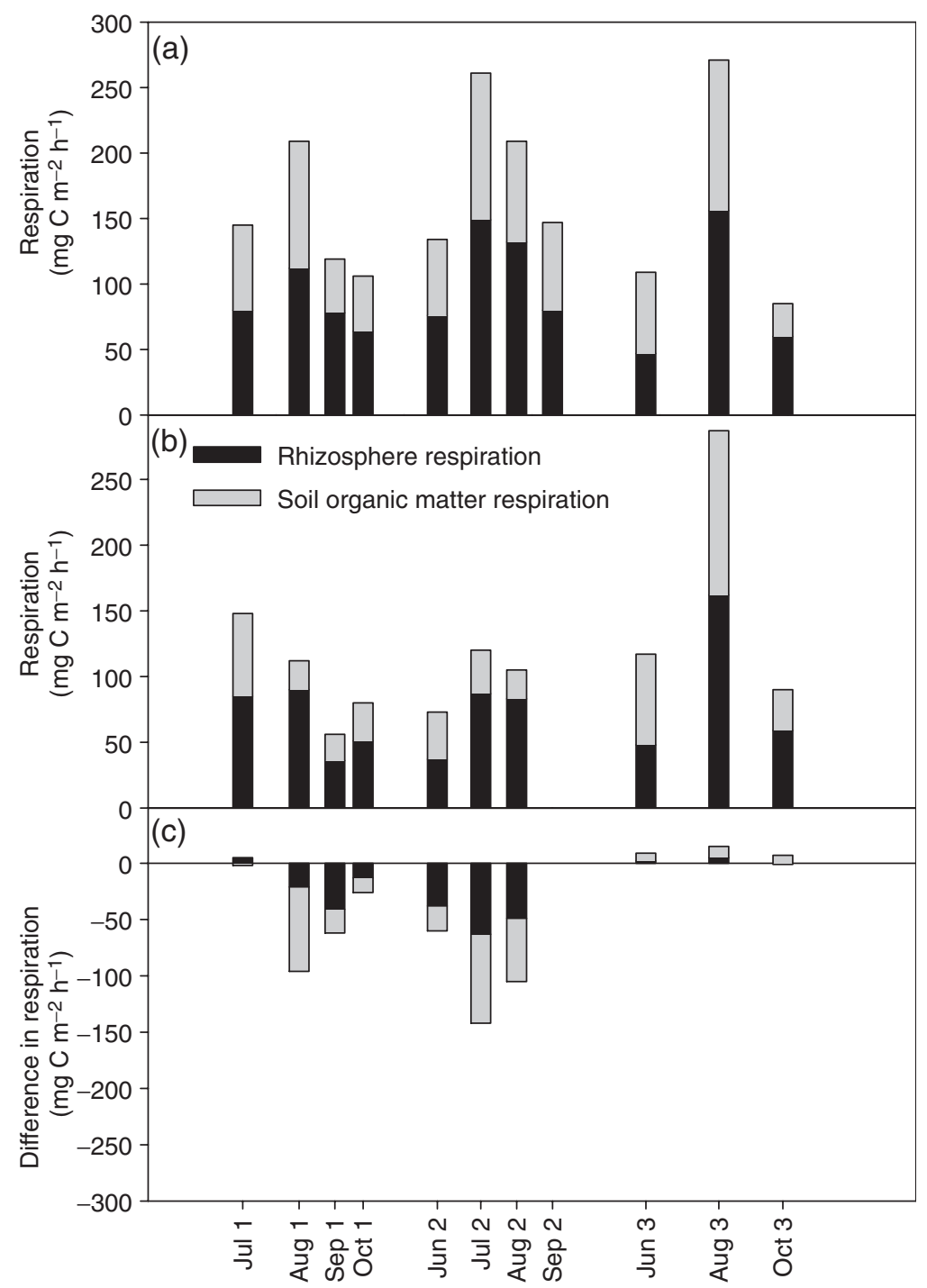

Fig. 8 Partitioning of soil respiration into rhizosphere respiration and SOM respiration in (a) the control plots, (b) the exclusion plots , and (3) the differences in SOM respiration between the exclusion and control plots at 11 occasions during the growing seasons in 20012003. We used an endmember of $139 \%$ o for SOM respiration in this calculation.

estimated daily evapotranspiration of $3-4 \mathrm{~mm}$ into account (Greenland, 1996), PAW of $109 \mathrm{~mm}$ may last for approximately 31 days in June-August. Trees may also have access to water that is stored in fissures and clefts of the bedrock. Goulden et al. (1996) showed that total respiration of this forest decreased by $30 \%$ or $100 \mathrm{~g} \mathrm{~m}^{-2}$ in the extremely dry summer of 1995 but photosynthesis decreased by only $10 \%$, suggesting a stronger effect of drought on heterotrophs than on autotrophs. Similarly, the decay of organic matter in the O horizon may be more severely affected by summer droughts than RR in the $\mathrm{O}$ horizon. The red oak that dominates this forest may be able to tolerate moderate drought because its root system penetrates more deeply than many cooccurring species, such as red maple (Abrams, 1990).
The partitioning of SR supports this conclusion, because the portion respired from recently fixed carbon increased and the portion respired from older carbon decreased in the exclusion plots as compared with the control plots in 2002. An opposite result was found for the $\mathrm{A}$ and $\mathrm{B}$ horizon where the radiocarbon signature of soil air indicated a decrease of the portion of recently fixed carbon with decreasing water content. Because of the distinct pattern in the ${ }^{14} \mathrm{CO}_{2}$ signature, however, it appears that the $\mathrm{CO}_{2}$ production of the mineral soil made a minor contribution to total soil surface $\mathrm{CO}_{2}$ efflux. Although the radiocarbon signature of surface efflux represents a mixture of all $\mathrm{CO}_{2}$ sources, the $\mathrm{O}$ horizon must have released somewhat younger carbon with increasing drought, and this was the dominant 
effect on total SR. Gaudinski et al. (2000) found $64 \%$ of total fine root detritus in the $\mathrm{O}$ horizon of an adjacent plot at the Harvard Forest suggesting that RR released large amounts of recently fixed carbon in the $\mathrm{O}$ horizon. Curiously, this result indicates that roots in the $\mathrm{O}$ horizon must remain relatively active even when the O horizon becomes very dry, suggesting a possible role for hydraulic lift (Caldwell et al., 1998).

The increasing age of $\mathrm{CO}_{2}$ with decreasing $\mathrm{CO}_{2}$ concentration and decreasing water content in the $\mathrm{A}$ and $\mathrm{B}$ horizon, could be because of fungal decomposition of old SOM in the mineral soil, because fungi are better adapted to soil drought than heterotrophic bacteria (Swift et al., 1979). We speculate that the development of fruiting bodies and high belowground activity of a saprophytic fungus was responsible for the efflux of old carbon on August 1, 2001 in both the exclusion and control plots. The release of old carbon was associated with the highest SR rate in 2001, indicating that this fruiting fungus respired relatively large amounts of oldSOM-derived carbon during this period. We do not know the extent to which fungi can store carbon to use for rapid growth of fruiting bodies, so we do not know if fungal decomposition rates also increased. Further research is needed to evaluate the function of fungi in the decomposition of relative resistant $\mathrm{SOM}$ in forest soils and the possibility of episodic pulses of $\mathrm{CO}_{2}$ efflux during periods of prolific mushroom production.

The linear relationship of differences in SR and soil water content between the exclusion and control plots (Fig. 4) suggests that the magnitude of the $\mathrm{CO}_{2}$ peak following wetting is most parsimoniously explained by the change in water content and the intensity of wetting. However, the response of SR to wetting was weak in the exclusion plots after the removal of roof panels in September 2001 and 2002, considering that easily decomposable carbon could have accumulated during the simulated droughts because of death of microorganisms (van Gestel et al., 1991) and desorption of SOM from mineral soil surfaces (Seneviratne \& Wild, 1985).

The weak response to wetting in September may be related to soil temperature. Our empirical model indicates the increasing importance of soil water content in the Oe/Oa horizon with increasing soil temperature on SR (Fig. 5). A similar relationship using soil temperature and water potential of the $\mathrm{O}$ horizon was described by Hanson et al. (2003) for incubated samples of the $\mathrm{O}$ horizon from a mixed deciduous forest near Oak Ridge, Tennessee. They concluded from their study that frequent drying and wetting of the $\mathrm{O}$ horizon may strongly affect the rate of total SR. Borken et al. (1999) reported a strong wetting effect on SR at high temperatures during July and a rather weak effect at low temperature in September in an exclusion experiment in Germany. Not only the duration of drought period but also the temperature at wetting may affect annual SR rate and perhaps the storage of SOM.

Drying and wetting of soil may mobilize carbon sources of different stability and age. The changes in the radiocarbon value of opposite signs following laboratory wetting of samples from the $\mathrm{O}$ and A horizons of the exclusion plots may result from this effect. A stimulation of the decay of organic matter that was fixed by plants in the 1960s-1990s would cause an increase in bomb carbon released, but a stimulation of decomposition of SOM originally fixed by plants prior to atmospheric weapons testing in the 1950s would cause a decrease in the release of radiocarbon. In case of the field-moist (i.e. dry A horizon in 2002) the latter process may have dominated because the radiocarbon value of $46 \%$ was below that of the atmosphere. Similarly, the radiocarbon value of SR dropped to $54 \%$ in the exclusion plots after the first heavy rainfall in September 2002, suggesting that prebomb carbon became available for microorganisms. The ${ }^{14} \mathrm{CO}_{2}$ signature as a mixture of respired prebomb, postbomb, and modern carbon can be misleading in terms of calculating turnover times of SOM under very dry and subsequent wetting conditions.

Our throughfall exclusion experiment did not simulate the total ecosystem response to soil drought because water uptake by entire trees was probably not affected by the exclusion of throughfall in our $5 \times 5 \mathrm{~m}^{2}$ treatment plots. Lateral movement of water and hydraulic lift may have also contributed water input to the mineral soil within the treatment plots. Hence, the volumetric water content of the mineral soil followed the same seasonal trend in the control and exclusion plots. We did not want to exclude RR in the small exclusion plots, so plots were not trenched. Because roots within exclusion plots may have been supplied with carbohydrates and water from the surrounding tree roots, RR may have been higher in the exclusion plots than would be the case during a natural drought of same severity. Reductions in rainfall throughout the entire forest stand may have diminished SR more strongly. On the other hand, a whole-ecosystem treatment could have a variety of effects on C cycling, including more allocation of $\mathrm{C}$ belowground for deep root growth, less RR and more root mortality in dry horizons, more decomposition of dead roots, and less decomposition of dry organic matter in the $\mathrm{O}$ horizon. After 3 years of throughfall exclusion of an entire 1 ha plot in an Amazonian forest, Davidson et al. (2004) have yet to observe a net effect on soil $\mathrm{CO}_{2}$ efflux despite a clear treatment effect on $\mathrm{N}_{2} \mathrm{O}$ and $\mathrm{CH}_{4}$ fluxes and on tree growth and mortality. Therefore, the integrated effects of drought on the ecosystem $\mathrm{C}$ balance is probably complicated by many interacting process responses. 
The partitioning of SR at the Harvard Forest suggests that the decay of SOM decreased more during extended summer droughts than did RR. We hypothesized that extended summer droughts can, at least temporarily, increase the storage of SOM in the O horizon, particularly when subsequent wetting occurs at low temperatures. In total, $311 \mathrm{~g} \mathrm{C} \mathrm{m}^{-2}$ or $38 \%$ less carbon was respired in the exclusion plots during the two summer periods of throughfall exclusion. Assuming that about $60 \%$ of this amount can be attributed to a decrease in the decay of SOM and the other $40 \%$ to a decrease in RR, then about $190 \mathrm{~g} \mathrm{C} \mathrm{m}^{-2}$ may have remained undecomposed in the $\mathrm{O}$ horizon and as SOM during the two treatment years. This inhibition of decomposition of about $95 \mathrm{~g} \mathrm{C} \mathrm{m}^{-2} \mathrm{yr}^{-1}$ caused by experimental drought is significant compared with annual NEE rates of 120 $250 \mathrm{~g} \mathrm{C} \mathrm{m}^{-2} \mathrm{yr}^{-1}$ between 1992 and 2000 at the Harvard Forest (Barford et al., 2001). Severe summer droughts occur, on average, once every 4 years at this site (Savage \& Davidson, 2001), and their effect on decomposition, especially in the $\mathrm{O}$ horizon, may contribute significantly to interannual variation in NEE.

In contrast to dry summers, wet summers may accelerate the decomposition of SOM as long as $\mathrm{O}_{2}$ availability is not limited. Goulden et al. (1996) found high values of total ecosystem respiration but low values of NEE during wet summers, suggesting that less carbon was sequestered in soil, perhaps because of greater rates of decomposition in moist conditions. However, SR in the exclusion plots increased only by $46 \mathrm{~g} \mathrm{C} \mathrm{m}^{-2}$ during the posttreatment period in 2002/2003.

We do not know if the $C$ that was not decomposed during the experimental droughts of 2001 and 2002 was very gradually decomposed at undetectable rates during the subsequent fall, winter, and spring, when we sampled infrequently, if it may have leached as DOC, if it was transformed into more resistant SOM that is persisting as a $\mathrm{C}$ sink, or if some of the undecomposed dry litter was simply blown away by the wind and decomposed later elsewhere in the landscape. Hence, we cannot conclude whether the apparent soil C sink during drought years in this experiment was transient or long-lasting. If the apparent sink of $190 \mathrm{~g} \mathrm{C} \mathrm{m}^{-2}$ over 2 years of throughfall exclusion was persistent, that would be only a $9 \%$ increase in the standing stock of the $\mathrm{O}$ horizon, which would be difficult to detect by inventory measurements, because of high spatial variability of the $\mathrm{O}$ horizon depth.

In a throughfall exclusion study in a hardwood forest at Oak Ridge, Tennessee, the opposite problem was encountered, where no detectable change in SR was observed but a change in $\mathrm{O}$ horizon standing stock was detected. Similar to our study, Hanson et al. (2003) documented decreased SR during natural summer drought. In contrast to our results, however, they reported only a $22 \mathrm{~g} \mathrm{C} \mathrm{m}^{-2}$ average annual decrease in SR in the throughfall exclusion plot compared with a control plot, and the difference was not statistically significant. Their 0.64 ha study plot was much larger than ours, and the soils of their site are also very deep $(>10 \mathrm{~m})$ compared with the thin Harvard Forest soils $(<1 \mathrm{~m})$ on glacial till, which probably has implications for PAW. Curiously, Johnson et al. (2002) reported a $40 \%$ increase in standing stocks of $\mathrm{O}$ horizon mass in the same plot after 5 years of throughfall exclusion compared with the control plot. Changes in stocks could not be attributed to differences in litterfall, suggesting a long-term treatment effect on litter decomposition. The O horizon mass accumulation caused by throughfall exclusion in that experiment was equivalent to about $45 \mathrm{~g} \mathrm{C} \mathrm{m}^{-2} \mathrm{yr}^{-1}$, which is only two times larger than the nonsignificant treatment effect on SR and only $5 \%$ of the annual SR rates reported by Hanson et al. (2003). Given the typically large temporal and spatial heterogeneity of SR, it is not surprising that a change of only $45 \mathrm{~g} \mathrm{C} \mathrm{m}^{-2} \mathrm{yr}^{-1}$ might not be detected with statistical confidence using SR measurements. Therefore, even frequent seasonal measurements of soil $\mathrm{CO}_{2}$ efflux may not always be good indicators of treatment effects on soil C stocks at multi-year time scales. The same may be true, but perhaps to a lesser degree, at our more northern Harvard Forest site in Massachusetts, where $\mathrm{O}$ horizon standing $\mathrm{C}$ stocks are larger and SR rates are smaller than in more southern hardwood forests of Tennessee.

Our results show that interannual variability in climate appears to affect the source/sink strength of forest soils, thus potentially affecting interannual variation in NEE. These results cannot be simply extrapolated to the effects of long-term, persistent changes in climate, however, climatic disruption will also affect long-term patterns of NPP, C allocation, and C inputs to soils. These results do clearly show, however, that drought can reduce $S R$ independently of temperature, that $R R$ was less affected by drought than was decay of organic matter, that the drought effect was manifest primarily in the $\mathrm{O}$ horizon, and that these responses to drought caused at least a transient sink of carbon.

\section{Acknowledgments}

We thank the summer interns Rosa Navarro, Chris Arabia, Linda Wan, Amanda Brown, Jeff Law, Naomie Clark and Nicole Nowinski for their hard work in the field. W. Borken acknowledges the financial support received by the Deutsche Forschungsgemeinschaft. This research was supported by the Office of Science (BER), US Department of Energy, through the Northeast Regional Center of the National Institute for Global Environmental Change under Cooperative Agreement No. DE-FC02-03ER63613. 


\section{References}

Abrams MC (1990) Adaptations and responses to drought in Quercus species of north America. Tree Physiology, 7, 227-238.

Barford CC, Wofsy SC, Goulden ML et al. (2001) Factors controlling long- and short-term sequestration of atmospheric $\mathrm{CO}_{2}$ in a mid-latitude forest. Science, 294, 1688-1691.

Borken W, Davidson EA, Savage K et al. (2003) Drying and wetting effects on $\mathrm{CO}_{2}$ release from organic horizons. Soil Science Society of America Journal, 67, 1888-1896.

Borken W, Xu YJ, Brumme R et al. (1999) A climate change scenario for carbon dioxide and dissolved organic carbon fluxes from a temperate forest soil: drought and rewetting effects. Soil Science Society of America Journal, 63, 1848-1855.

Caldwell MM, Dawson TE, Richards JH (1998) Hydaulic lift: consequences of water efflux from the roots of plants. Oecologia, 113, 151-161.

Davidson EA, Belk E, Boone RD (1998) Soil water content and temperature as independent or confounded factors controlling soil respiration in a temperate mixed hardwood forest. Global Change Biology, 4, 217-227.

Davidson EA, Ishida FY, Nepstad DC (2004) Effects of an experimental drought on soil emissions of carbon dioxide, methane, nitrous oxide, and nitric oxide in a moist tropical forest. Global Change Biology, 10, 718-730.

Davidson EA, Trumbore SE (1995) Gas diffusivity and production of $\mathrm{CO}_{2}$ in deep soils of the eastern Amazon. Tellus Series B, 47, 550-565.

Eswaran H, Van Den Berg E, Reich P (1993) Organic carbon in soils of the world. Soil Science Society of America Journal, 57, 192-194.

Foster D (1992) Land use history (1730-1990) and vegetation dynamics in Central New England, USA. Journal of Ecology, 80, 753-772.

Gaudinski JB, Trumbore SE, Davidson EA et al. (2000) Soil carbon cycling in a temperate forest: radiocarbon-based estimates of residence times, sequestration rates and partitioning of fluxes. Biogeochemistry, 51, 33-69.

Goulden ML, Munger JM, Fan S-M et al. (1996) Exchange of carbon dioxide by a deciduous forest: response to interannual climate variability. Science, 271, 1576-1578.

Greenland D (1996) Harvard Forest. A climate analysis of longterm ecological research sites. [Online]. [5 p.] Available at http:/ /intranet.lternet.edu/archives/documents/Publications/ climdes/hfr/hfrclim.htm (accessed 22 July 2002; verified 15 January 2003). The US Long Term Ecological Research Network. Albuquerque, NM.
Hanson PJ, O'Neill EG, Chambers MLS et al. (2003) Soil respiration and litter decomposition. In: North American Temperate Deciduous Forest Responses to Changing Precipitation Regimes (eds Hanson PJ, Wullschleger SD), pp. 163-189. Springer, New York.

Howard DM, Howard PJA (1993) Relationship between $\mathrm{CO}_{2}$ evolution, moisture content and temperature for a range of soil types. Soil Biology \& Biochemistry, 25, 1537-1546.

IPCC (2001) Climate Change 2001: the Scientific Basis. In: Contribution of Working Group I to the Third Assessment Report of the Intergovernmental Panel on Climate Change (eds Houghton JT et al.), Cambridge University Press, Cambridge, U.K.

Johnson DW, Hanson PJ, Todd DE Jr. (2002) The effects of throughfall manipulation on soil leaching in a deciduous forest. Journal of Environmental Quality, 31, 204-216.

Levin I, Hesshaimer V (2000) Radiocarbon - a unique tracer of global carbon cycle dynamics. Radiocarbon, 42, 69-80.

Orchard VA, Cook FJ (1983) Relationship between soil respiration and soil moisture. Soil Biology \& Biochemistry, 15, 447-453.

Savage K, Davidson EA (2001) Interannual variation of soil respiration in two new England forests. Global Biochemical Cycles, 15, 337-350.

Savage K, Davidson EA (2003) A comparison of manual and automated systems for soil $\mathrm{CO}_{2}$ flux measurements: tradeoffs between spatial and temporal resolution. Journal of Experimental Botany, 54, 891-899.

Seneviratne R, Wild A (1985) Effect of mild drying on the mineralization of soil nitrogen. Plant and Soil, 84, 175-179.

Skopp J, Jawson MD, Doran JW (1990) Steady-state aerobic microbial activity as a function of soil water content. Soil Science Society of America Journal, 54, 1619-1625.

Stuiver M, Polach H (1977) Reporting of ${ }^{14} \mathrm{C}$ data. Radiocarbon, 19, 355-363.

Sundquist ET (1993) The global carbon dioxide budget. Science, 259, 934-941.

Swift MJ, Heal OW, Anderson JM (1979) Decomposition in Terrestrial Ecosystems. Blackwell Scientific, Oxford, UK.

Systat Software 2001 Systat 10.0 for Windows: Statistics. Systat Software Inc., Richmond, CA.

Trumbore SE (2000) Age of soil organic matter and soil respiration: radiocarbon constraints on belowground $\mathrm{C}$ dynamics. Ecological Applications, 10, 399-411.

van Gestel M, Ladd JN, Amato M (1991) Carbon and nitrogen mineralization from two soils of contrasting texture and microaggregate stability: influence of sequential fumigation, drying and storage. Soil Biology \& Biochemistry, 23, 313-322.

Vogel JS (1992) A rapid method for preparation of biomedical targets for AMS. Radiocarbon, 34, 344-350. 